\title{
Aggregate breakdown and surface seal development influenced by rain intensity, slope gradient and soil particle size
}

\author{
S. Arjmand Sajjadi and M. Mahmoodabadi \\ Department of Soil Science, Agriculture Faculty, Shahid Bahonar University of Kerman, Kerman, Iran \\ Correspondence to: M. Mahmoodabadi (mahmoodabadi@uk.ac.ir)
}

Received: 6 October 2014 - Published in Solid Earth Discuss.: 16 December 2014

Revised: 15 February 2015 - Accepted: 16 February 2015 - Published: 5 March 2015

\begin{abstract}
Aggregate breakdown is an important process which controls infiltration rate (IR) and the availability of fine materials necessary for structural sealing under rainfall. The purpose of this study was to investigate the effects of different slope gradients, rain intensities and particle size distributions on aggregate breakdown and IR to describe the formation of surface seal. To address this issue, 60 experiments were carried out in a $35 \times 30 \times 10 \mathrm{~cm}$ detachment tray using a rainfall simulator. By sieving a sandy loam soil, two sub-samples with different maximum aggregate sizes of $2 \mathrm{~mm}\left(D_{\max } 2 \mathrm{~mm}\right)$ and $4.75 \mathrm{~mm}\left(D_{\max } 4.75 \mathrm{~mm}\right)$ were prepared. The soils were exposed to two different rain intensities $\left(57\right.$ and $\left.80 \mathrm{~mm} \mathrm{~h}^{-1}\right)$ on several slopes $(0.5,2.5,5,10$ and $20 \%$ ) each at three replicates. The result showed that for all slope gradients and rain intensities, the most fraction percentages in soils $D_{\max } 2$ and $D_{\max } 4.75 \mathrm{~mm}$ were in the finest size classes of 0.02 and $0.043 \mathrm{~mm}$, respectively. The soil containing finer aggregates exhibited higher transportability of pre-detached material than the soil containing larger aggregates. Also, IR increased with increasing slope gradient, rain intensity and aggregate size under unsteady state conditions because of less development of surface seal. However, under steady state conditions, no significant relationship was found between slope and IR. The findings of this study revealed the importance of rain intensity, slope steepness and soil aggregate size on aggregate breakdown and seal formation, which can control infiltration rate and the consequent runoff and erosion rates.
\end{abstract}

\section{Introduction}

Soil erosion is one of the most serious environmental problems in the world (Leh et al., 2013; Lieskovský and Kenderessy, 2014). Soil erosion affects forests and agricultural lands and is a key factor for land degradation (Cerdà et al., 2009; Mahmoodabadi, 2011; Mandal and Sharda, 2013); it also explains the changes in landforms, soil and water resources and the recovery of vegetation (García Orenes et al., 2009; García Fayos et al., 2010; Zhao et al., 2013). To improve the accuracy and precision of erosion models and develop more rationally based soil erosion control techniques, the development of process-based models is very important (Romkens et al., 2001; Haregeweyn et al., 2013). Raindrops that impact soil surface can influence erosion rate and change the structure of soil in various ways (Kinnell, 2005), although the size of the drops is a key factor (Cerdà, 1997). In this regard, surface seal is formed by raindrop impact, which further leads to slaking and breakdown of soil aggregates (Assouline, 2004). The development of surface seal depends on the extent of the breakdown of surface aggregates, which depends on soil structure stability (Pulido Moncada et al., 2013; Wick et al., 2014; Gelaw et al., 2015). This is directly related to the kinetic energy of raindrops, the rain intensity and the duration of the rainstorm as well as the stability of aggregates to resist such breakdown. However, vegetation cover is the key factor in reducing soil erosion through the reduction of crusting in the soil surface and the enhancement of infiltration (Cerdà et al., 1998; Gabarrón-Galeote et al., 2013; Brevik et al., 2015). Reduction of infiltration rate (IR), intensification of runoff and interference with seed germination are some of the consequences of surface sealing (Mermut et al., 1997).

Some studies have shown that seal formation is a key factor in soil erosion processes, because it can reduce the surface 
roughness as well as IR and soil loss by splash (Assouline and Mualem, 2000; Robinson and Phillips, 2001; Assouline, 2004; Assoualine and Ben-Hur, 2006). In general, aggregate breakdown occurs when its strength is reduced by wetting to a level where the stress imposed by raindrops is sufficient to disrupt the aggregate (Assouline, 2004). The main mechanisms of aggregate breakdown during water erosion processes are slaking by fast wetting and mechanical breakdown due to raindrop impact (Le Bissonnais, 1996; Legout et al., 2005; Shi et al., 2010). Therefore, a certain threshold kinetic energy is needed to start detachment (Lujan, 2003). Consequently, when aggregates are broken down by raindrops impact and/or slaking, the disaggregated particles are deposited within the upper soil pore spaces, forming a thin, dense and low-permeable layer, namely surface seal (Assouline, 2004).

Some studies have shown that when rainfall detachment is the dominant erosion process, the size distribution of the eroded soil differs from the original soil from which it was derived (Proffitt et al., 1993; Slattery and Burt, 1997). Also, aggregate breakdown due to the raindrop impact is likely to be a major factor affecting sediment size distribution in soil erosion experiments (Hairsine et al., 1999). Aggregate breakdown produces smaller particles than the original soil, which may then be displaced and reoriented into a more continuous structure. They clog conducting pores and, consequently, a surface seal is developed (Ramos et al., 2003). The particle size distribution of the eroded soil can be influenced by the particle size distribution of the original soil, the aggregate breakdown during erosion event and the settling velocity of different size classes of particles (Rose et al., 2007; Mahmoodabadi et al., 2014a). The particle size distribution of eroded soil also seems to be dependent on the erosive agent of rainfall and or runoff, flow hydraulic characteristics and slope gradient (Ruff et al., 2003; Sirjani and Mahmoodabadi, 2012).

Soil infiltration during a rainstorm is closely related to the intensity and kinetic energy of the rainfall, surface conditions and soil properties such as those related to aggregate stability (Hawke et al., 2006; Mazaheri and Mahmoodabadi, 2012). These can affect IR through the surface seal formation, which results from physico-chemical compaction and dispersion due to raindrop impact (Assouline, 2004). In addition, slope gradient is considered to play a key role in controlling IR and erosion rate (Essig et al., 2009; Mahmoodabadi and Cerdà, 2013). Ekwue et al. (2009) and Sirjani and Mahmoodabadi (2014) reported that soil erosion increased with increasing slope gradient as a result of reduced IR and greater runoff rate. Janeau et al. (2003) observed a reduction in IR when slope gradient increased. Poesen (1987) noted contradictory results dealing with the relationship between slope gradient and IR: on soils susceptible to surface seal formation, a decrease in IR with increasing slope gradient was found.

Soil infiltration is also highly dependent on rainfall intensity and the relationship between these two parameters has been studied (Foley and Silburn, 2002; Hawke et al., 2006). Foley and Silburn (2002) found that higher IR often occurred with greater rainfall intensities. Romkens et al. (1985) reported that raindrops can destroy or deform the arrangement of soil particles; therefore, the detached particles can clog the soil pores, again reducing the IR. Ribolzi et al. (2011) concluded that the kinetic energy of raindrops and associated risks of soil crusting also decrease on steeper slopes, which might lead to increasing IR. The soils of arid and semiarid regions due to low content of organic carbon are generally susceptible to surface sealing and erosion (Cerdà, 2000; Mahmoodabadi and Cerdà, 2013). Under these conditions, only a few studies have investigated aggregate breakdown and surface sealing. The objective of this study was to evaluate aggregate breakdown under different rain intensities, slope gradients and soil aggregate sizes by the determination of aggregate size distribution and to assess the formation and development of surface seal on the basis of obtained data of IR.

\section{Material and methods}

\subsection{Soil preparation and characteristics}

In this study, a soil sample was taken from the upper $20 \mathrm{~cm}$ of agricultural land. It was air dried and then passed separately through 2 and $4.75 \mathrm{~mm}$ sieves. Two soils with different maximum aggregate sizes were provided (Zamani and Mahmoodabadi, 2013), named $D_{\max } 2 \mathrm{~mm}$ and $D_{\max } 4.75 \mathrm{~mm}$. Note there were no primary particles coarser than $2 \mathrm{~mm}$ in the soils because the original soil was collected from agricultural land. Some physical and chemical properties were measured for both sub-samples separately. Texture of the soils was determined using the hydrometer method (Gee and Or, 2002). Aggregate size distribution was determined by wet and dry sieving (Kemper and Rosenau, 1986). Also, some chemical properties of the soils including $\mathrm{pH}$ and $\mathrm{EC}$ were measured in a soil: water suspension with a ratio of $1: 5$. Organic carbon content was determined as described by Walkley and Black (1934), and the percentage of $\mathrm{CaCO}_{3}$ equivalent was measured using the titration method (Pansu and Gautheyrou, 2006). The measured physical and chemical properties of the soils are listed in Table 1. The obtained results showed that the mean weight diameter in terms of dry and wet for soil $D_{\max } 4.75 \mathrm{~mm}$ was 0.78 and $0.3 \mathrm{~mm}$, respectively, while these parameters for soil $D_{\max } 2 \mathrm{~mm}$ had lower values. Both soils showed a very low organic carbon content $(<1 \%)$, whereas the content of $\mathrm{CaCO}_{3}$ equivalent, which is dominant in arid and semiarid region soils, was higher than $10 \%$ (Mazaheri and Mahmoodabadi, 2012). The fraction percentage of aggregates for the soils is also shown in Fig. 1. For both soils $D_{\max } 2$ and $D_{\max } 4.75 \mathrm{~mm}$ the most frequent size classes were found to be in the range of 0.063 to $0.5 \mathrm{~mm}$ with 75.9 and $79.9 \%$, respectively, while larger and finer size classes were lower. 
Table 1. Some physical and chemical properties of the soils used in the experiments.

\begin{tabular}{lcc}
\hline Soil properties & $\begin{array}{c}\text { Soil containing particles finer } \\
\text { than } 2 \mathrm{~mm}\left(D_{\max } 2 \mathrm{~mm}\right)\end{array}$ & $\begin{array}{c}\text { Soil containing particles finer } \\
\text { than } 4.75 \mathrm{~mm}\left(D_{\max } 4.75 \mathrm{~mm}\right)\end{array}$ \\
\hline Sand $(\%)$ & 58.8 & 56.6 \\
Silt $(\%)$ & 23.4 & 31.3 \\
Clay $(\%)$ & 17.8 & 12.1 \\
Dry MWD $(\mathrm{mm})$ & 0.46 & 0.78 \\
Wet MWD $(\mathrm{mm})$ & 0.26 & 0.3 \\
OC $(\%)$ & 0.9 & 0.75 \\
pH & 7.13 & 7.47 \\
$\mathrm{EC}\left(\mathrm{dS} \mathrm{m}^{-1}\right)$ & 3.11 & 3.31 \\
$\mathrm{CaCO}_{3}(\%)$ & 17.4 & 21 \\
\hline
\end{tabular}

MWD: mean weight diameter, EC: electrical conductivity, OC: organic carbon.

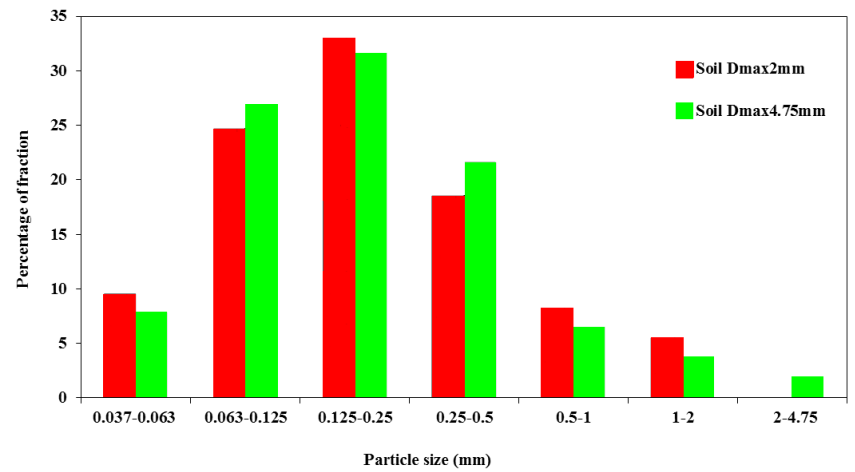

Figure 1. The fraction percentage obtained by the wet sieving procedure.

\subsection{Treatments and experimental setup}

In total, 60 experiments were carried out using the prepared soil samples under different rain intensities of 57 and $80 \mathrm{~mm} \mathrm{~h}^{-1}$ and several slopes $(0.5,2.5,5,10$ and $20 \%)$, each at three replicates. For this purpose, an experiment was done with a rainfall simulator to generate different rain intensities (Bodí et al., 2012; Mahmoodabadi and Cerdà, 2013; MorenoRamón et al., 2014). The nozzle used in the rainfall simulator was a pressurized one which was placed $1.5 \mathrm{~m}$ above the soil surface (Fig. 2). In order to measure rain intensity, 16 containers $(6.8 \mathrm{~cm}$ diameter $)$ were placed at regular distances under the simulated rains (Mahmoodabadi et al., 2007). To assess the uniformity of rain intensity, Christiansen's coefficient was calculated (Grierson and Oades, 1977):

$\mathrm{CC}=\left[1-\frac{\sum\left|x_{\mathrm{i}}-m\right|}{m \cdot n}\right] \times 100$,

where $x_{\mathrm{i}}$ is the measured intensity in each container, $m$ is the average rain intensity and $n$ is the number of containers. Also, the measurement of average drop size was done using the stain method (Arjmand Sajjadi and Mahmoodabadi, 2015). The average ( \pm standard deviation) drop sizes for the

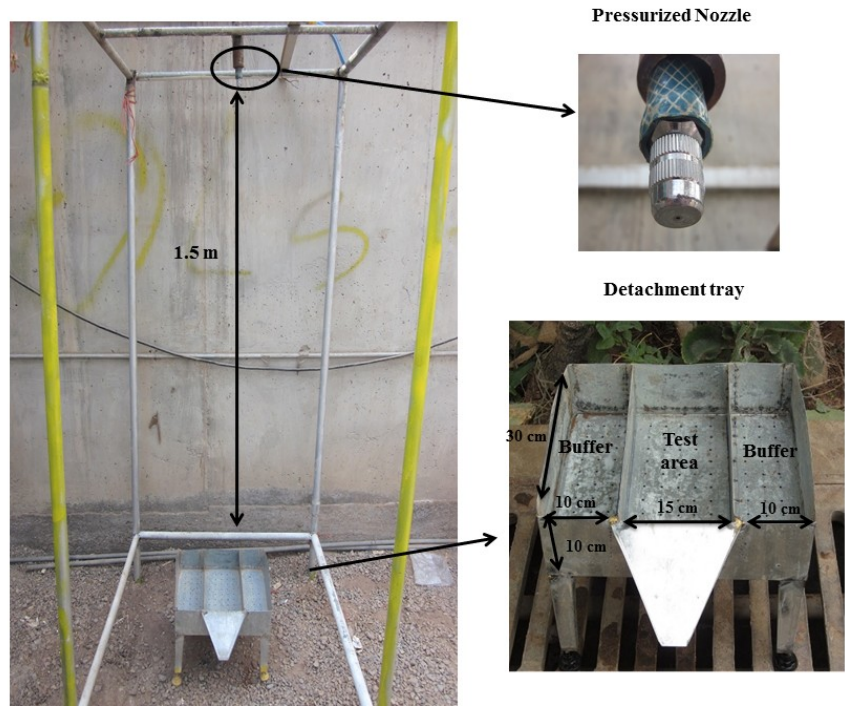

Figure 2. The rainfall simulator and detachment tray used in the experiments.

rain intensities of 57 and $80 \mathrm{~mm} \mathrm{~h}^{-1}$ were $2.2 \pm 0.08$ and $2.5 \pm 0.09 \mathrm{~mm}$ with the coefficient of uniformity of 86 and $80 \%$, respectively.

A $35 \times 30 \mathrm{~cm}$ drainable tray with $10 \mathrm{~cm}$ depth was used in the experiments (Fig. 2). The washed sediment was collected from the central test area of the tray. On two sides of the test area a buffer section was provided so the soil was not only lost by splash but could also be returned from the buffer area (Arjmand Sajjadi and Mahmoodabadi, 2015). Different parts of the applied detachment tray are shown in Fig. 2.

\subsection{Rainfall simulation experiments}

Before every experiment, each soil sample was saturated for $24 \mathrm{~h}$. Afterward, the drainage water was removed out of the tray. Simulated rainfall lasted until a constant runoff rate was reached (40-45 min). For each rainfall event, the sediment- 
laden overland flow was sampled at time intervals $(2,5,15$, 20, 30 and $40 \mathrm{~min}$ ) and volumetrically measured. Collected samples were deposited, separated from the water and dried in an oven at $105^{\circ} \mathrm{C}$ for $24 \mathrm{~h}$. In addition, stream power as one of the hydraulic parameters was used, as defined by Mahmoodabadi et al. (2014b):

$\Omega=\rho g q S$

where $\Omega$ is stream power $\left(\mathrm{W} \mathrm{m}^{-2}\right), \rho$ is water mass density $\left(\mathrm{kg} \mathrm{m}^{-3}\right), g$ is the gravitational acceleration $\left(\mathrm{m} \mathrm{s}^{-2}\right), q$ $\left(\mathrm{m}^{-2} \mathrm{~s}\right)$ is volumetric flux per unit width and $S$ is the gradient of bed slope $\left(\mathrm{m} \mathrm{m}^{-1}\right)$.

During each experiment, infiltrated water was collected from the bottom of the detachment tray at different time intervals. Since the soil was saturated during each run, aggregate breakdown and the resultant size redistribution compared to the original soil were attributed to the seal formation. Therefore, at the end of each experiment the upper $5 \mathrm{~mm}$ of soil surface was sampled for the determination of aggregate size distribution. Aggregate size distribution of the eroded soil was measured by wet sieving (Kemper and Rosenau, 1986). For this purpose, soil aggregates were submerged and gently sieved into clear water, while each sample was sieved for 2 min. For soil $D_{\max } 2 \mathrm{~mm}$, six sieves of $1,0.5,0.25,0.125$, 0.063 and $0.037 \mathrm{~mm}$ were used, and for soil $D_{\max } 4.75 \mathrm{~mm}$, one additional sieve of $2 \mathrm{~mm}$ was used. Then, remaining aggregates on each sieve were dried in oven at $105^{\circ} \mathrm{C}$ for $24 \mathrm{~h}$.

For quantification of aggregate breakdown of the eroded soils, fraction percentage was determined for each size class compared to non-eroded (original) soil. The obtained data from the wet sieving of the original soil were subdivided into 10 size classes using the interpolation method, each having an equal mass fraction (10\%). Also, both soil samples were subdivided 10 size classes. Finally, the fraction of each size class was obtained using the subdivision of equal classes obtained from the original soil as described in Mahmoodabadi and Sirjani (2012). Thereupon, the fraction of the eroded soils for each experiment was calculated based on the size classes of the original soil. All statistical analyses were performed in the SAS statistical framework; to obtain the main differences between the treatments, the Duncan's $(\alpha=0.05)$ test was applied.

\section{Results and discussion}

\subsection{Rain-induced particle size redistribution}

The fraction percentages of 10 size classes of soil $D_{\max } 2 \mathrm{~mm}$ created by different rain intensities and slope gradients, are compared to the original soil in Fig. 3. The fraction percentage of the original soil was indicated in Fig. 3 by uniform fraction of $10 \%$ in each size class. When the fraction percentage of each size class (10 size classes of eroded soil) was greater than $10 \%$, the size class increased on the soil sur- face. Generally, the fraction percentage of the size class of $0.02 \mathrm{~mm}$ was the highest among all the rain intensities and slope gradients. This size class was affected by decreasing in the fraction percentage of coarser size classes. Therefore, the fraction percentage in coarser size classes decreased while the opposite was found in finer size classes.

For the rain intensity of $57 \mathrm{~mm} \mathrm{~h}^{-1}$ and $0.5 \%$ slope gradient, the fraction percentage of eroded soil in the range of $0.055-0.092 \mathrm{~mm}$ was slightly greater than that of the original soil (Fig. 3a). The fraction percentage in the range of $0.121-$ $0.411 \mathrm{~mm}$ decreased and was slightly higher in the coarsest size class $(1.5 \mathrm{~mm})$ than the original soil. At $2.5 \%$ slope gradient, the fraction percentage in the size class of $0.055 \mathrm{~mm}$ was higher than the original soil; the fraction percentages decreased in size classes coarser than $0.073 \mathrm{~mm}$ (Fig. 3b). At $5 \%$ slope gradient, the fraction percentage in the range of $0.055-0.092 \mathrm{~mm}$ was higher, whereas it was less than the original soil in the size classes from 0.121 to $0.411 \mathrm{~mm}$ (Fig. 3c). However, for rain intensity of $57 \mathrm{~mm} \mathrm{~h}^{-1}$, the fraction percentage of the coarsest size class $(1.5 \mathrm{~mm})$ increased compared to the original soil. At 10 and $20 \%$ slope gradients, the fraction percentages increased in size classes ranged from 0.055 to $0.092 \mathrm{~mm}$, while those size classes coarser than $0.121 \mathrm{~mm}$ decreased compared to the original soil (Fig. 3d and e).

In the comparison case, for the rain intensity of $80 \mathrm{~mm} \mathrm{~h}^{-1}$ and in all slope gradients (Fig. 3) the fraction percentage in the range of $0.055-0.092 \mathrm{~mm}$ was higher than the original soil (except $5 \%$ slope gradient). In contrast, in the size classes coarser than $0.121 \mathrm{~mm}$, the fraction percentage decreased compared to the original soil for all slope gradients (except $5 \%$ slope gradient). At $5 \%$ slope gradient, the fraction percentage in the range of $0.055-0.073 \mathrm{~mm}$ was higher; in size classes coarser than $0.092 \mathrm{~mm}$, it was less than the original soil.

The obtained results for soil $D_{\max } 2 \mathrm{~mm}$ exhibited some differences in the two applied rain intensities. The first difference refers to the fraction percentage in the size class of $0.02 \mathrm{~mm}$, which was higher in rain intensity of $57 \mathrm{~mm} \mathrm{~h}^{-1}$ than that obtained in rain intensity of $80 \mathrm{~mm} \mathrm{~h}^{-1}$. This means that in rain intensity of $57 \mathrm{~mm} \mathrm{~h}^{-1}$, however, the aggregates were broken down by raindrop impact during the rainfall event and produced finer particles; the resultant surface flow did not have enough transportability to carry detached particles way out of the test area. Therefore, the fraction percentage of the finest size class $(0.02 \mathrm{~mm})$ was enhanced in the eroded soil under the lower rain intensity $\left(57 \mathrm{~mm} \mathrm{~h}^{-1}\right)$. In contrast, the higher rain intensity of $80 \mathrm{~mm} \mathrm{~h}^{-1}$ caused more detachability of soil aggregates and higher flow rates, which intensified transportability of finer pre-detached materials as well. Asadi et al. (2011) reported that with increasing flow stream power, sediment size distribution became coarser, finally becoming similar to or even coarser than the original soil; therefore, finer sediment remained on the soil surface. 

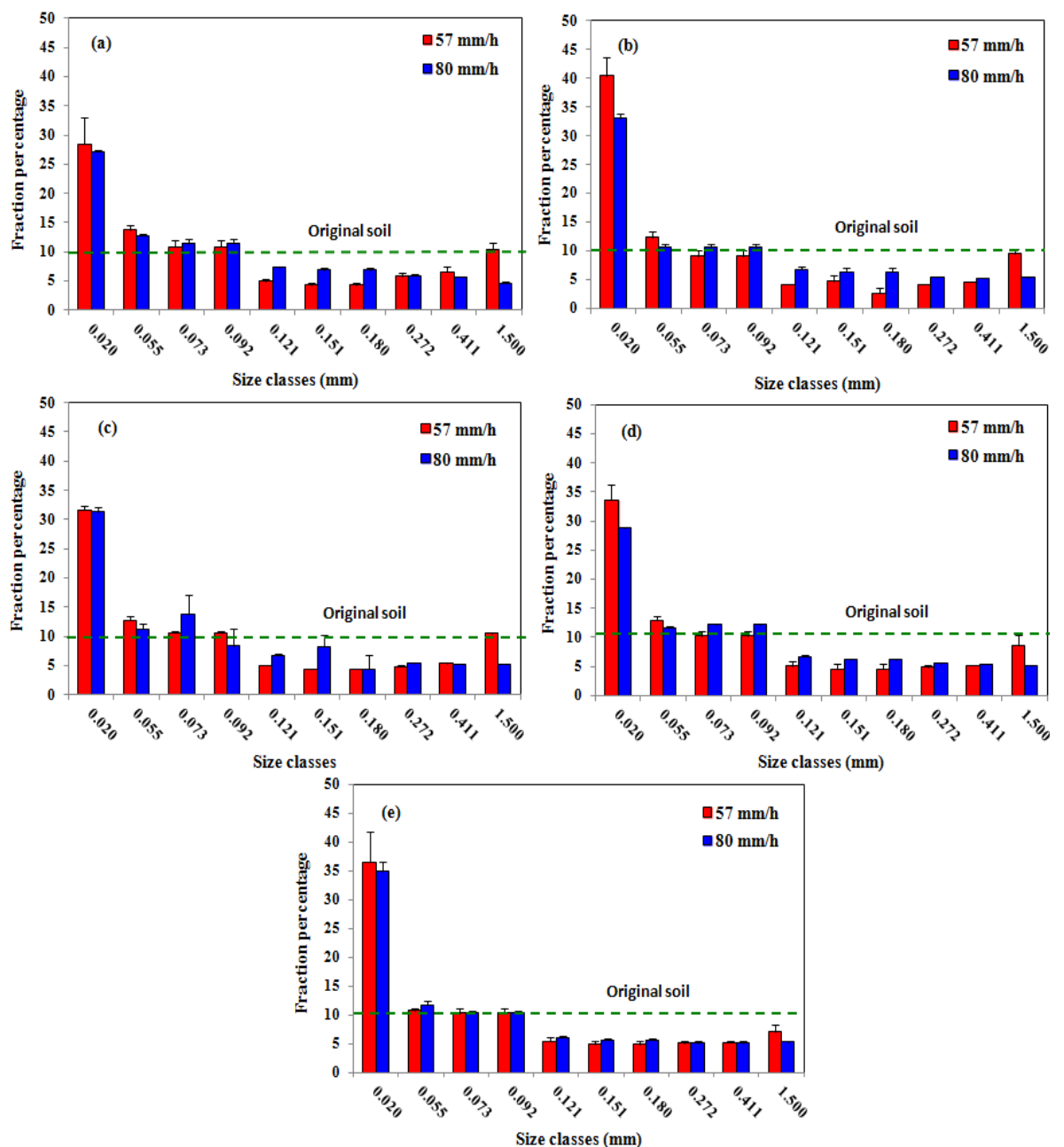

Figure 3. Comparison of particle size distribution in eroded soil $D_{\max } 2 \mathrm{~mm}$ compared to the original soil for different slopes of (a) 0.5 , (b) 2.5 , (c) 5 , (d) 10 and (e) $20 \%$. Error bars represent standard errors of the means.

The second difference can be related to the coarsest size class $(1.5 \mathrm{~mm})$, which showed higher fraction percentage in rain intensity of $57 \mathrm{~mm} \mathrm{~h}^{-1}$ than that observed in $80 \mathrm{~mm} \mathrm{~h}^{-1}$. Since the erosive force of raindrops in the higher rain intensity $\left(80 \mathrm{~mm} \mathrm{~h}^{-1}\right)$ was higher than rain intensity of $57 \mathrm{~mm} \mathrm{~h}^{-1}$, much larger aggregates were broken down. Consequently, the coarser particles size percentage was reduced under $80 \mathrm{~mm} \mathrm{~h}^{-1}$ rain intensity compared to the lower rain intensity. In addition, the rain intensity of $80 \mathrm{~mm} \mathrm{~h}^{-1}$ generated higher flow rates leading to higher transportability of aggregates. Meyer et al. (1980) found that the percentage of coarser particles in eroded sediment was higher for more intense rainstorms. Beuselink et al. (2000) reported that in lower stream powers, finer particles were transported selectively and large particles remained on soil surface; however, with increasing stream power, larger particles were also transported.

The obtained result for soil $D_{\max } 4.75 \mathrm{~mm}$ and rain intensity of $57 \mathrm{~mm} \mathrm{~h}^{-1}$ showed that the fraction percentage for size class of $0.043 \mathrm{~mm}$ were the highest, which implied a considerable increase compared to the original soil in all slope gradients (Fig. 4). For this lower rain intensity, the fraction percentage in the coarsest size class $(3.375 \mathrm{~mm})$ was more than the original soil for all slope gradients. Also, a reduction trend in the fraction percentage was found in the size class of 0.064 to $0.433 \mathrm{~mm}$. Similarly, for the rain intensity of $80 \mathrm{~mm} \mathrm{~h}^{-1}$, the most fraction percentage was placed at the finest size class $(0.043 \mathrm{~mm})$ and the size classes coarser than $0.064 \mathrm{~mm}$ showed less fraction percentages than the original soil in all the slopes (Fig. 4).

A comparison of the fraction percentages for soil $D_{\max } 4.75 \mathrm{~mm}$ under different rain intensities (Fig. 4) showed that in both rain intensities, the most fraction percentage compared to the original was the finest size class $(0.043 \mathrm{~mm})$. However, for the rain intensity of $80 \mathrm{~mm} \mathrm{~h}^{-1}$, the fraction percentage of the finest size class was higher than that obtained for the intensity of $57 \mathrm{~mm} \mathrm{~h}^{-1}$. In contrast, the fraction percentage of the coarsest size $(3.375 \mathrm{~mm})$ was reduced 

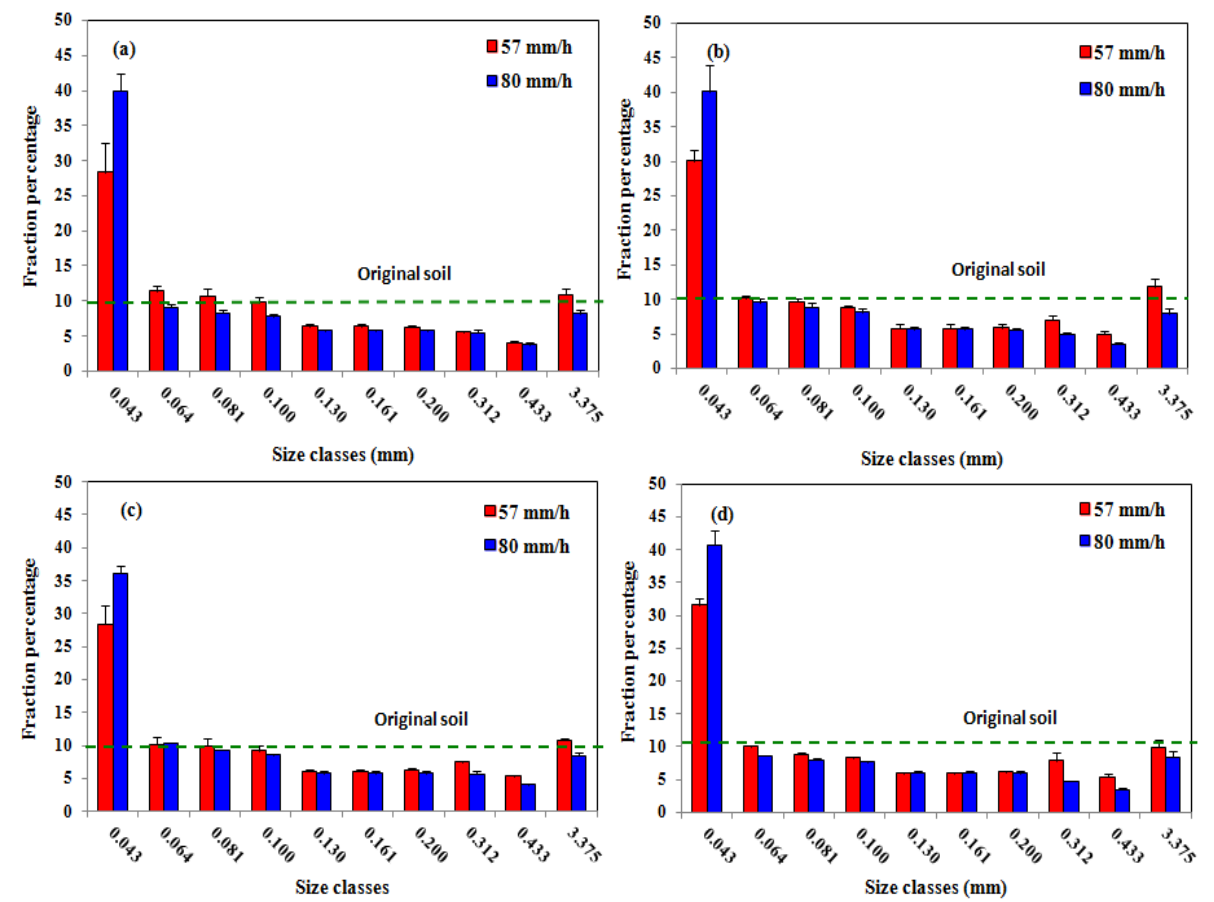

Size classe

Size classes $(\mathrm{mm})$

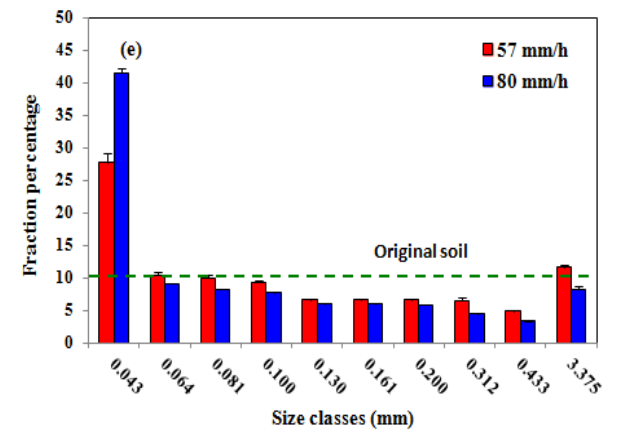

Figure 4. Comparison of particle size distribution in eroded soil $D_{\max } 4.75 \mathrm{~mm}$ compared to the original soil and for different slopes of (a) 0.5 , (b) 2.5 , (c) 5, (d) 10 and (e) $20 \%$. Error bars represent standard errors of the means.

at higher rain intensity $\left(80 \mathrm{~mm} \mathrm{~h}^{-1}\right)$ compared to the lower intensity $\left(57 \mathrm{~mm} \mathrm{~h}^{-1}\right)$. The result for the finest size class is contradictory to soil $D_{\max } 2 \mathrm{~mm}$ may be partly due to the fact that the soil containing larger aggregates exhibited higher infiltration rate and lower flow rates (Mazaheri and Mahmoodabadi, 2012). The result showed that the flow stream power generated on soil $D_{\max } 2 \mathrm{~mm}$ and soil $D_{\max } 4.75 \mathrm{~mm}$ ranged from 0.0007 to 0.0346 and from 0.0004 to $0.0313 \mathrm{~W} \mathrm{~m}^{-2}$, respectively. In other words, the higher the rain intensity introduced on soil $D_{\max } 4.75 \mathrm{~mm}$, the greater amounts of finer particles were produced. Nevertheless, because of higher infiltration rate of this soil, the stream power of generated flow seems not to be enough to transport and move out all the predetached materials from the test area (Arjmand Sajjadi and Mahmoodabadi, 2015). This finding implies that the redistribution of particles or aggregates on the surface of eroding soil depends on aggregate size distribution as well as rain intensity and the resultant flow stream power.

\subsection{Time changes of infiltration rate}

Time changes of IR for soil $D_{\max } 2 \mathrm{~mm}$ under different rain intensities and slope gradients is presented in Fig. 5. For both rain intensities at the beginning of event, infiltration values were at the highest rates; meanwhile, the fluctuations of IR for different slope gradients were relatively high. Due to the time changes of IR in these first minutes, this period can be considered as unsteady state conditions. Under these conditions, higher IR values were obtained for the steepest slope $(20 \%)$. Towards the end of the event, the variations of IR were minimal. Also, it was reduced to reach steady state conditions as the changes of IR found to be negligible with time. The highest fluctuation of IR with time was found when IR was at the maximum value; therefore for each experiment, this value was assumed to be an unsteady IR. To compare these two conditions, results of variance analysis for measured IR under unsteady and steady state conditions are pre- 
Table 2. Analysis of variance for the applied treatments on measured infiltration rate under unsteady and steady state conditions.

\begin{tabular}{lccc}
\hline Source of Variation & D.F. & $\begin{array}{c}\text { Mean square for } \\
\text { unsteady state conditions }\end{array}$ & $\begin{array}{c}\text { Mean square for } \\
\text { steady state conditions }\end{array}$ \\
\hline Slope (A) & 4 & $116.2^{* *}$ & $4.2^{\mathrm{ns}}$ \\
Rain intensity(B) & 1 & $3207.8^{* *}$ & $57.4^{* *}$ \\
Particle size distribution (C) & 1 & $69.4^{* *}$ & $199.3^{* *}$ \\
$\mathrm{~A} \times \mathrm{B}$ & 4 & $63.8^{* *}$ & $3.9^{\mathrm{ns}}$ \\
$\mathrm{A} \times \mathrm{C}$ & 4 & $209.8^{\mathrm{ns}}$ & $3.9^{\mathrm{ns}}$ \\
$\mathrm{B} \times \mathrm{C}$ & 1 & $3431.1^{* *}$ & $3.8^{\mathrm{ns}}$ \\
$\mathrm{A} \times \mathrm{B} \times \mathrm{C}$ & 4 & $205.6^{\mathrm{ns}}$ & $0.2^{\mathrm{ns}}$ \\
Error & 40 & 4.1 & 3 \\
Coefficient Variation & - & 6.3 & 19.3 \\
\hline
\end{tabular}

* significant at 0.05 probability; ${ }^{* *}$ significant at 0.01 probability level; ns: non significant.

sented in Table 2. As is obvious, the single effects of rain intensity and soil particle size distribution on IR were significant under both unsteady and steady conditions. In contrast, the influence of slope gradient on IR was just significant in an unsteady state, whereas no significant effect was found under steady state conditions.

Since the studied soils remained saturated during the rainfall, the time changes of IR can only be attributed to seal formation. The results indicated that the surface seal was less-developed during the first minutes and become more developed with the progress of time. This explanation can be applied for the effects of slope gradient on IR under two different steady and unsteady state conditions. Under unsteady state conditions and at steeper slopes, higher values of IR were observed. This means that surface sealing could not be developed at steeper slopes due to the depletion of pre-detached materials by sheet flow. Poesen (1986) inferred that increased IR on steeper slopes can result from reduced surface sealing. In some studies, no significant relationship was found between slope gradient and IR (e.g., Singer and Blackard, 1982; Mah et al., 1992; Martínez-Murillo et al., 2013), whereas in others, a reduction in IR with increasing slope gradient was reported (e.g., Chaplot and Le Bissonnais, 2000; Essig et al., 2009). Fox et al. (1997) observed a reduction in IR with increasing slope gradient until a critical threshold was reached; thereafter, IR was found to be irrelevant to slope gradient. More counterintuitive are the studies that showed an increase in IR with increasing slope gradient (e.g., Poesen, 1986; Cerdà, 1999; Assouline and Ben-Hur, 2006).

In a steady state, lower rates of infiltration were observed compared to the unsteady state conditions. In addition, the effect of slope gradient on steady IR was insignificant (Table 2). According to Fig. 3, the aggregate breakdown due to raindrop impact produced finer aggregates, which were used to form a surface seal with lower hydraulic conductivity than the original soil. Freebairn et al. (1989) attributed the reduction in IR during rainfall in both laboratory and field
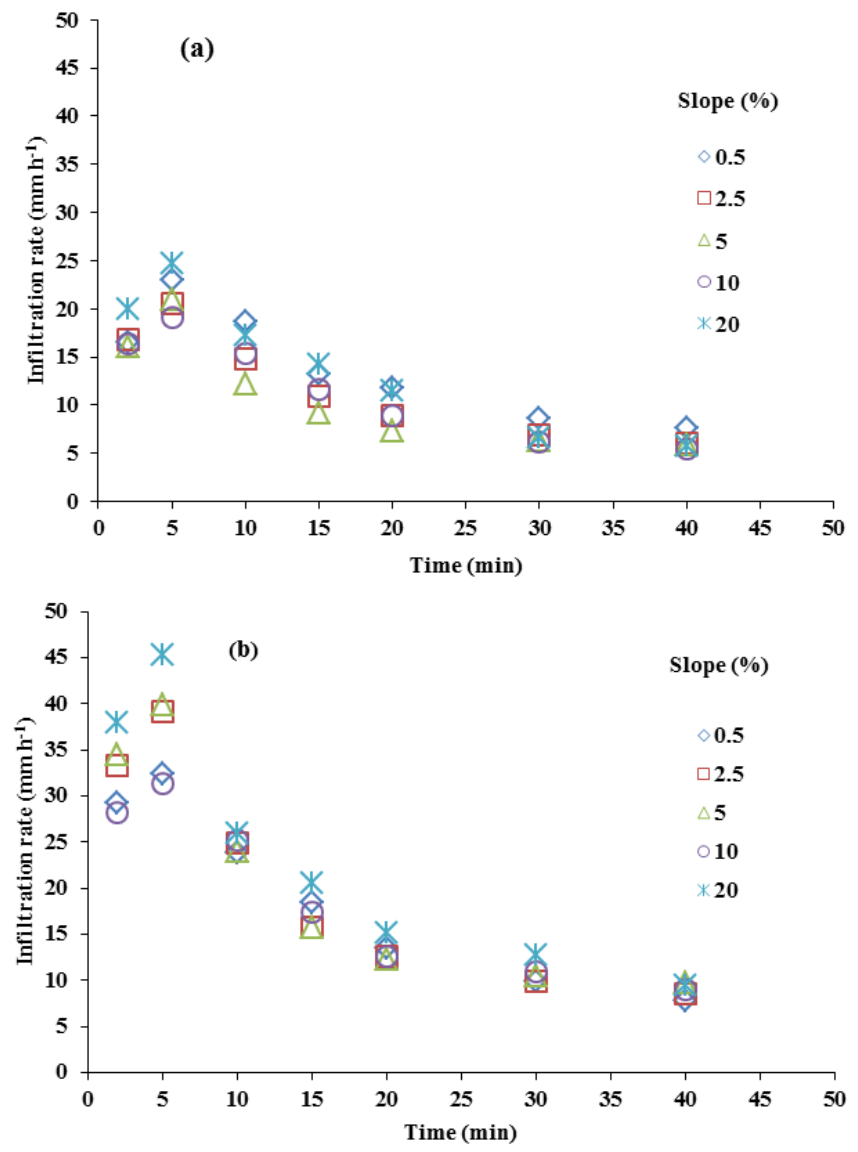

Figure 5. Time changes of infiltration rate in soil $D_{\max } 2 \mathrm{~mm}$ for different slope gradients and rain intensities of (a) 57 and (b) $80 \mathrm{~mm} \mathrm{~h}^{-1}$.

conditions to the formation of surface seal. Similarly, Moss and Watson (1991) reported that the reduction of IR is likely related to the obstruction of surface pores due to aggregate breakdown and seal formation.

A comparison of IR of the simulated rain intensities for soil $D_{\max } 2 \mathrm{~mm}$ (Fig. 5) implied that the higher rain inten- 

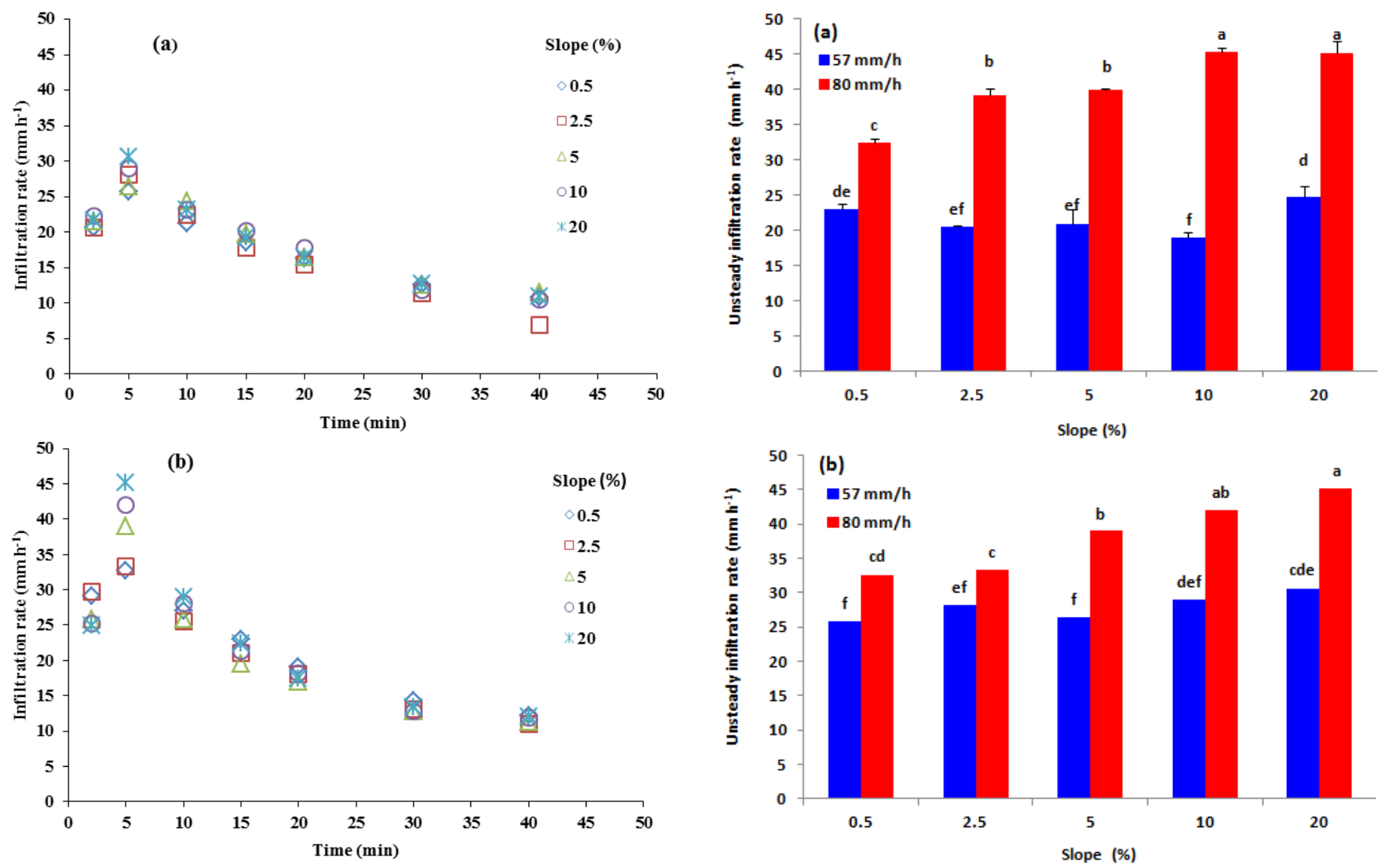

Figure 6. Time changes of infiltration rate in soil $D_{\max } 4.75 \mathrm{~mm}$ for different slope gradients and rain intensities of (a) 57 and (b) $80 \mathrm{~mm} \mathrm{~h}^{-1}$.

sity $\left(80 \mathrm{~mm} \mathrm{~h}^{-1}\right)$ led to greater IR values than those obtained for the lower rain intensity $\left(57 \mathrm{~mm} \mathrm{~h}^{-1}\right)$, particularly under unsteady state conditions. A plausible reason is that as rain intensity increased, the transportability of flow enhanced to carry detached particles way out of the test area. As discussed above, the finest size class $(0.02 \mathrm{~mm})$ showed a higher fraction percentage in rain intensity of $57 \mathrm{~mm} \mathrm{~h}^{-1}$ than that obtained in $80 \mathrm{~mm} \mathrm{~h}^{-1}$. However, some researchers (e.g., Foley and Silburn, 2002) reported an increase in IR due to higher rain intensities. In this regard, some inconsistent results have been reported (Liu et al., 2011; Schmidt et al., 2010). Liu et al. (2011) believed that the relationship between rain intensity and IR is reversed. Schmidt (2010) verified that higher rain intensities with more erosive impacts can increase the amount of runoff as a result of IR reduction. In our study, we show that in spite of the higher erosivity of more intense rain, the surface seal did not develope completely under unsteady state conditions because of washing out and removing fine soil particles.

Figure 6 shows the changes of IR with time for different rain intensities and slope gradients for soil $D_{\max } 4.75 \mathrm{~mm}$. The results of this soil are similar to those obtained for soil $D_{\max } 2 \mathrm{~mm}$. At the start of rain event, the unsteady IR fluctu-

Figure 7. Comparison of the unsteady infiltration rate for soil samples with the maximum particles size of (a) 2 and (b) $4.75 \mathrm{~mm}$ (error bars represent standard errors of the means and mean comparison using Duncan's test; $\alpha=0.05)$.

ated highly among different slope gradients, while over time it approached a nearly constant value for all slopes. The result indicated that the unsteady IR increased with increasing slope gradient. Also, increasing rain intensity increased IR under unsteady state conditions.

A considerable point observed in both soils (Figs. 5 and 6) is that the measured IR in soil $D_{\max } 4.75 \mathrm{~mm}$ was higher than in soil $D_{\max } 2 \mathrm{~mm}$. The reason for higher IR values in soil $D_{\max } 4.75 \mathrm{~mm}$ can be attributed to the existence of larger aggregate sizes and the subsequent larger pores. In addition, larger aggregate create a relatively rough surface; therefore, the generated runoff have enough time to infiltrate into the soil. 


\subsection{Unsteady IR}

The results of Table 2 indicate that the influence of slope on IR was significant just under unsteady state conditions. The effect of slope gradient and rain intensity on the unsteady IR for soil $D_{\max } 2 \mathrm{~mm}$ and $D_{\max } 4.75 \mathrm{~mm}$ is shown in Fig. 7. In general, the obtained unsteady IR increased as slope steepness increased, especially under the higher rain intensity. For soil $D_{\max } 2 \mathrm{~mm}$, the unsteady IR ranged from $19 \mathrm{~mm} \mathrm{~h}^{-1}$ at $10 \%$ slope to $24.7 \mathrm{~mm} \mathrm{~h}^{-1}$ at $20 \%$ slope under $57 \mathrm{~mm} \mathrm{~h}^{-1}$ rain intensity. In higher rain intensity $\left(80 \mathrm{~mm} \mathrm{~h}^{-1}\right)$, it varied from 32.4 to $45.2 \mathrm{~mm} \mathrm{~h}^{-1}$ as slope gradient increased from 0.5 to $20 \%$. Therefore, the unsteady IR under $80 \mathrm{~mm} \mathrm{~h}^{-1}$ was higher than $57 \mathrm{~mm} \mathrm{~h}^{-1}$ rain intensity. This finding was consistent with the results of Assouline and Ben-Hur (2006), who reported that infiltration rate and soil loss increased at higher rain intensities. This was attributed to a thinner and less developed seal layer resulting from higher erosion of the soil surface and lower component of drop impact. Thus, the probable reason for the difference between the applied rain intensities in the present study may be partly as a consequence of greater stream power due to the higher rain intensity of $80 \mathrm{~mm} \mathrm{~h}^{-1}$ in removing fine soil particles and underdevelopment of surface seal.

For soil $D_{\max } 4.75 \mathrm{~mm}$, as slope gradient increased from 0.5 to $20 \%$ the unsteady IR values due to rain intensities of 57 and $80 \mathrm{~mm} \mathrm{~h}^{-1}$ ranged from 25.7 to $30.6 \mathrm{~mm} \mathrm{~h}^{-1}$ and from 32.6 to $45.1 \mathrm{~mm} \mathrm{~h}^{-1}$, respectively. Therefore, for soil $D_{\max } 4.75 \mathrm{~mm}$ similar to soil $D_{\max } 2 \mathrm{~mm}$, the unsteady IR was higher under rain intensity of $80 \mathrm{~mm} \mathrm{~h}^{-1}$ than that under $57 \mathrm{~mm} \mathrm{~h}^{-1}$. In both rain intensities, the unsteady IR values were higher at steeper slopes for both soils. This means that at steeper slopes and under unsteady state conditions due to faster depletion of pre-detached soil particles seal layer was less developed, which enhanced the infiltration of water into the soil.

\section{Conclusions}

Considering the obtained fraction percentage in size classes for both eroded soils, the percentage of the finest particles was found to increase compared to the original soil, whereas the reverse result was found for larger aggregates. Also, an increase in rain intensity led to an intensification of aggregate breakdown; however, the effect of rain intensity on the contribution of fraction percentage in size classes depended on the aggregate size. In addition, the soil containing finer aggregates exhibited relatively easy transportability of the predetached material in comparison to the soil containing larger aggregates. Since the studied soils remained saturated during the rainfall event, the change of infiltration rate with time was only attributed to seal formation. The surface seal was found to be less developed during the first minutes, while it formed a more developed seal layer with the progress of time. Fur- thermore, the result showed that the measured infiltration rate increased with increasing rain intensity, aggregate size and slope under unsteady state conditions because of less development of the surface seal. However, under steady state conditions, no significant relationship was found between slope and the measured infiltration rate, which was attributed to the development of surface seal. In a steady state, lower rates of infiltration were observed compared to the unsteady state conditions. In addition, the soil containing larger aggregates exhibited higher rates of infiltration as this soil was less sensitive to raindrop impact and seal formation. The findings of this study highlight the importance of rain intensity, slope steepness and soil aggregate size on aggregate breakdown and seal formation that can control infiltration rate and the consequent runoff and erosion rates.

Acknowledgements. This work was supported by the Soil Science Department, Faculty of Agriculture, Shahid Bahonar University of Kerman, which is greatly acknowledged.

Edited by: A. Cerdà

\section{References}

Arjmand Sajjadi, S. and Mahmoodabadi, M.: Sediment concentration and hydraulic characteristics of rain-induced overland flows in arid land soils, J. Soil. Sedim., 15, 710-721, doi:10.1007/s11368-015-1072-z, 2015.

Asadi, H., Moussavi, A., Ghadiri, H., and Rose, C. W.: Flow-driven soil erosion processes and the size selectivity of sediment, J. Hydrol., 406, 73-81, 2011.

Assouline, S.: Rainfall-induced soil surface sealing: a critical review of observations, conceptual models, and solutions, Vadose Zone J., 3, 570-591, 2004.

Assouline, S. and Ben-Hur, M.: Effect of rainfall intensity and slope gradient on the dynamics of interrill erosion during soil surface sealing, Catena, 66, 211-220, 2006.

Assouline, S. and Mualem, Y.: Modeling the dynamics of seal formation: analysis of the effect of soil and rainfall properties, Water Resour. Res., 36, 2341-2349, 2000.

Beuselinck, L., Govers, G., Steegen, A., and Quine, T. A.: Sediment transport by overland flow over an area of net deposition, Hydrol. Proc., 13, 2769-2782, 1999.

Bodí, M. B., Doerr, S. H., Cerdà, A., and Mataix-Solera, J.: Hydrological effects of a layer of vegetation ash on underlying wettable and water repellent soils, Geoderma, 191, 14-23, 2012.

Brevik, E. C., Cerdà, A., Mataix-Solera, J., Pereg, L., Quinton, J. N., Six, J., and Van Oost, K.: The interdisciplinary nature of soil, Soil, 1, 117-129, 2015.

Cerdà, A.: Rainfall drop size distribution in Western Mediterranean Basin, València, Spain, Catena, 31, 23-38, 1997.

Cerdà, A.: The influence of aspect and vegetation on seasonal changes in erosion under rainfall simulation on a clay soil in Spain, Can. J. Soil Sci., 78, 321-330, 1998. 
Cerdà, A.: Seasonal and spatial variations in infiltration rates in badland surfaces under Mediterranean climatic conditions, Water Resour. Res., 35, 319-328, 1999.

Cerdà, A.: Aggregate stability against water forces under different climates on agriculture land and scrubland in southern Bolivia, Soil Till. Res., 36, 1-8, 2000.

Cerdà, A., Giménez-Morera, A. Y., and Bodí, M. B.: Soil and water losses from new citrus orchards growing on sloped soils in the western Mediterranean basin, Earth Surf. Proc. Land., 34, 18221830, 2009.

Chaplot, V. and Le Bissonnais, Y.: Field measurements of interrill erosion under different slopes and plot sizes, Earth Surf. Proc. Land., 25, 145-153, 2000.

Ekwue, E. I., Bharat, C., and Samaroo, K.: Effect of soil type, peat and farmyard manure addition, slope and their interactions on wash erosion by overland flow of some Trinidadian soils, Biosyst. Engin., 102, 236-243, 2009.

Essig, E. T., Corradini, C., Morbidelli, R., and Govindaraju, R. S.: Infiltration and deep flow over sloping surfaces: Comparison of numerical and experimental results, J. Hydrol., 374, 30-42, 2009.

Foley, J. L. and Silburn, D. M.: Hydraulic properties of rain impact surface seals on three clay soils influence of raindrop impact frequency and rainfall intensity during steady state, Austr. J. Soil Res., 40, 1069-1083, 2002.

Fox, D. M., Bryan, R. B., and Price, A. G.: The influence of slope angle on final infiltration rate for interrill conditions, Geoderma, 80, 181-194, 1997.

Freebairn, D. M., Gupta, S. C., and Rawls, W. J.: Influence of aggregate size and microrelief on development of surface soil crusts, Soil Sci. Soc. Am. J., 55, 188-195, 1991.

Gabarrón-Galeote, M. A., Martínez-Murillo, J. F., Quesada, M. A., and Ruiz-Sinoga, J. D.: Seasonal changes in the soil hydrological and erosive response depending on aspect, vegetation type and soil water repellency in different Mediterranean micro environments, Solid Earth, 4, 497-509, doi:10.5194/se-4-497-2013, 2013.

García-Orenes, F., Cerdà, A., Mataix-Solera, J., Guerrero, C., Bodí, M. B., Arcenegui, V., Zornoza, R., and Sempere, J. G.: Effects of agricultural management on surface soil properties and soilwater losses in eastern Spain, Soil Till. Res., 106, 117-123, 2009.

García-Fayos, P., Bochet, E., and Cerdà, A.: Seed removal susceptibility through soil erosion shapes vegetation composition, Plant Soil, 334, 289-297, 2010.

Gee, G. W. and Or, D.: Particle size analysis. In: Dane, J. H., and Topp, G. C. (Eds.): Methods of Soil Analysis, Part 4. Physical Mmethods, Soil Science Society of America, Book Series, No. 5, ASA and SSA Madison, WI, 255-293, 2002.

Gelaw, A. M., Singh, B. R., and Lal, R.: Organic carbon and nitrogen associated with soil aggregates and particle sizes under different land uses in Tigray, northern Ethiopia, Land Degrad. Dev., doi:10.1002/ldr.2261, 2015.

Grierson, I. T. Y. and Oades, J. M.: A rainfall simulator for field studies of runoff and erosion, J. Agr. Engin. Res., 22, 37-44, 1977.

Hairsine, P. B., Sander, G. C., Rose, C. W., Parlange, J. Y., Hogarth, W. L., Lisle, I., and Rouhipour, H.: Unsteady soil erosion due to rainfall impact: a model of sediment sorting on the hillslope, J. Hydrol., 199, 115-128, 1999.
Haregeweyn, N., Poesen, J., Verstraeten, G., Govers, G., de Vente, J., Nyssen, J., Deckers, J., and Moeyersons, J.: Assessing the performance of a spatially distributed soil erosion and sediment delivery model (WATEM/SEDEM) in Northern Ethiopia, Land Degrad. Dev., 24, 188-204, 2013.

Hawke, R. M., Price, A. G., and Bryan, R. B.: The effect of initial soil water content and rainfall intensity on near-surface soil hydrologic conductivity: a laboratory investigation, Catena, 65, 237-346, 2006.

Janeau, J. L., Briquet, J. P., Planchon, O., and Valentin, C.: Soil crusting and infiltration on steep slopes in northern Thailand, Europ. J. Soil Sci., 54, 543-553, 2003.

Kemper, W. D. and Rosenau, R. C.: Aggregate stability and size distribution, in: Methods of Soil Analysis, Part 1. Physical and Mineralogical Methods, edited by: Klute, A., American Society of Agronomy, Madison, Wisconsin, 425-442, 1986.

Kinnell, P. I. A.: Raindrop impact induced erosion processes and prediction: A review, Hydrol. Proc., 19, 2815-2844, 2005.

Le Bissonnais, Y.: Aggregate stability and assessment of soil crustability and erodibility: I. Theory and methodology, Europ. J. Soil Sci., 47, 425-437, 1996.

Legout, C., Leguédois, S., Le Bissonnais, Y., and Issa, O. M.: Splash distance and size distributions for various soils, Geoderma, 124, 279-292, 2005.

Leh, M., Bajwa, S., and Chaubey, I.: Impact of land use change on erosion risk: an integrated remote sensing geographic information system and modeling methodology, Land Degrad. Dev., 24, 409-421, 2013.

Lieskovský, J. and Kenderessy, P.: Modelling the effect of vegetation cover and different tillage practices on soil erosion in vineyards: a case study in Vrable (Slovakia) using WATEM/SEDEM, Land Degrad. Dev., 25, 288-296, 2014.

Liu, H., Lei, T. W., Zhao, J., Yuan, C. P., Fan, Y. T., and Qu, L. Q.: Effects of rainfall intensity and antecedent soil water content on soil infiltrability under rainfall conditions using the run off-onout method, J. Hydrol., 396, 24-36, 2011.

Lujan, D. L.: Soil physical properties affecting soil erosion in tropical soils, Lecture given at the College on Soil Physics, Trieste, 3-21 March, 2003.

Mah, M. G. C., Douglas, L. A., and Ringrose-Voase, A. J.: Effects of crust development and surface slope on erosion by rainfall, Soil Sci., 154, 37-43, 1992.

Mahmoodabadi, M.: Sediment yield estimation using a semiquantitative model and GIS- remote sensing data, Internat. Agrophys., 25, 241-247, 2011.

Mahmoodabadi, M. and Cerdà, A.: WEPP calibration for improved predictions of interrill erosion in semi-arid to arid environments, Geoderma, 204/205, 75-83, 2013.

Mahmoodabadi, M. and Sirjani, E.: Study on sediment transport mechanisms due to sheet erosion using flume experiment, J. Watershed Engin. Manage., 4, 1-11, 2012 (in Persian).

Mahmoodabadi, M., Rouhipour, H., Arabkhedri, M., and Rafahi, H. G.: Intensity calibration of SCWMRI rainfall and erosion simulator, J. Watershed Manage. Sci. Engin., 1, 39-50, 2007 (in Persian).

Mahmoodabadi, M., Ghadiri, H., Bofu, Y., and Rose, C.: Morphodynamic quantification of flow-driven rill erosion parameters based on physical principles, J. Hydrol., 514, 328-336, 2014a. 
Mahmoodabadi, M., Ghadiri, H., Rose, C., Bofu, Y., Rafahi, H., and Rouhipour, H.: Evaluation of GUEST and WEPP with a new approach for the determination of sediment transport capacity, J. Hydrol., 513, 413-421, 2014b.

Mandal, D. and Sharda, V. N.: Appraisal of soil erosion risk in the Eastern Himalayan region of India for soil conservation planning, Land Degrad. Dev., 24, 430-437, 2013.

Martínez-Murillo, J. F., Nadal-Romero, E., Regüés, D., Cerdà, A., and Poesen, J.: Soil erosion and hydrology of the western Mediterranean badlands throughout rainfall simulation experiments: a review, Catena, 106, 101-112, 2013.

Mazaheri, M. R. and Mahmoodabadi, M.: Study on infiltration rate based on primary particle size distribution data in arid and semi arid region soils, Arab. J. Geosci., 5, 1039-1046, 2012.

Mermut, A. R., Luk, S. H., Romkens, M. J. M., and Poesen, J. W. A.: Soil loss by splash and wash during rainfall from two loess soils, Geoderma, 75, 203-214, 1997.

Meyer, L. D., Harmon, W. C., and McDowell, L. L.: Sediment size eroded from crop row sideslopes, Trans. ASAE, 23, 891-898, 1980.

Moreno-Ramón, H., Quizembe, S. J., and Ibáñez-Asensio, S.: Coffee husk mulch on soil erosion and runoff: experiences under rainfall simulation experiment, Solid Earth, 5, 851-862, doi:10.5194/se-5-851-2014, 2014.

Moss, A. J. and Watson, C. L.: Rain-impact soil crust III. Effects of continuous and flawed crusts on infiltration and the ability of plant cover to maintain crustal flaws, Austr. J. Soil Res., 29, 311330, 1991.

Pansu, M. and Gautheyrou, J.: Handbook of soil analysis, mineralogical, organic and inorganic methods, Springer, Heidelberg, p. 993, 2006.

Poesen, J.: Surface sealing as influenced by slope angle and position of simulated stone sin the top layer of loose sediments, Earth Surf. Proc. Land., 11, 1-10, 1986.

Poesen, J.: The role of slope angle in surface seal formation, in: Proc. 1st International Conference on Geomorphology: Geomorphology, Resource Environment and Developing World, edited by: Gardner, V., John Wiley and Sons, New York, 437-448, 1987.

Proffitt, A. P. B., Hairsine, P. B., and Rose, C. W.: Modelling soil erosion by overland flow: application over a range of hydraulic conditions, Trans. ASAE, 36, 1743-1753, 1993.

Pulido Moncada, M., Gabriels, D., Cornelis, W., and Lobo, D.: Comparing aggregate stability tests for soil physical quality indicators, Land Degrad. Dev., doi:10.1002/ldr.2225, 2013.

Ramos, M. C., Nacci, S., and Pla, I.: Effect of raindrop impact and its relationship with aggregate stability to different disaggregation forces, Catena, 53, 365-376, 2003.
Ribolzi, O., Patin, J., Bresson, L. M., Latsachack, K. O., Mouche, E., Sengtaheuanghoung, O., Silvera, N., Thiebaux, J. P., and Valentin, C.: Impact of slope gradient on soil surface features and infiltration on steep slopes in northern Laos, Geomorphology, 127, 53-63, 2011.

Robinson, D. A. and Phillips, C. P.: Crust development in relation to vegetation and agricultural practice on erosion susceptible, dispersive clay soils from central and southern Italy, Soil Till. Res., 60, 1-9, 2001.

Romkens, M., Baumhardt, R., Parlange, J., Whistler, F., Parlange, M., and Prasad, S.: Rain-induced surface seals: their effect on ponding and infiltration, Ann. Geophys. (Series B), 4, 17-424, 1985.

Romkens, M. J. M., Helming, K., and Prasad, S. N.: Soil erosion under different rainfall intensities, surface roughness and soil water regimes, Catena, 46, 103-123, 2001.

Rose, C. W., Yu, B., Ghadiri, H., Asadi, H., Parlange, J. Y., Hogarth, W. L., and Hussein, J.: Dynamic erosion of soil in steady sheet flow, J. Hydrol., 333, 449-458, 2007.

Schmidt, J.: Effects of soil slaking and sealing on infiltrationexperiments and model approach, Proceedings of the 19th World Congress of Soil Science: Soil solutions for a changing world, Brisbane, Australia, 1-6 August 2010, the physics of soil pore structure dynamics, 29-32, 2010.

Shi, Z. H., Yan, F. L., Li, L., Li, Z. X., and Cai, C. F.: Interrill erosion from disturbed and undisturbed samples in relation to topsoil aggregate stability in red soils from subtropical China, Catena, 81, 240-248, 2010.

Singer, M. J. and Blackard, J.: Slope angle-interrill soil loss relationships for slopes up to $50 \%$, Soil Sci. Soc. Am. J., 46, 1270 1273, 1982.

Sirjani, E. and Mahmoodabadi, M.: Study on flow erosivity indicators for predicting soil detachment rate at low slopes, Internat. J. Agr. Sci., Res. Technol., 2, 55-61, 2012.

Sirjani, E. and Mahmoodabadi, M.: Effects of sheet flow rate and slope gradient on sediment load, Arab. J. Geosci., 7, 203-210, 2014.

Slattery, M. C. and Burt, T. P.: Particle size characteristics of suspended sediment in hillslope runoff and stream flow, Earth Surf Proc. Land., 22, 705-719, 1997.

Walkley, A. and Black, I. A.: An examination of the degtjareff method for determining soil organic matter, and proposed modification of the chromic acid titration method, Soil Sci., 37, 29-38, 1934.

Wick, A. F., Daniels, W. L. Nash, W. L., and Burger, J. A.: Aggregate recovery in reclaimed coal mine soils of SW Virginia, Land Degrad. Dev., doi:10.1002/ldr.2309, 2014.

Zamani, S. and Mahmoodabadi, M.: Effect of particle-size distribution on wind erosion rate and soil erodibility, Arch. Agr. Soil Sci., 59, 1743-1753, 2013.

Zhao, G., Mu, X., Wen, Z., Wang, F., and Gao, P.: Soil erosion, conservation, and Eco-environment changes in the Loess Plateau of China, Land Degrad. Dev., 24, 499-510, 2013. 